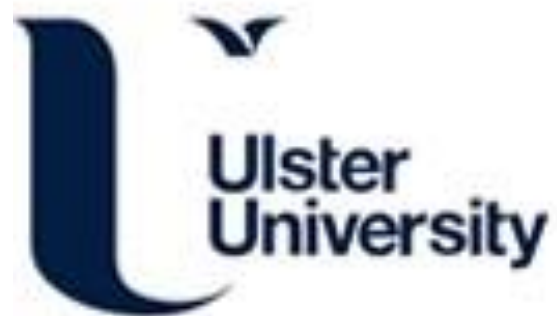

\section{Authoring Interactive Software Simulations for e-Learning}

Paris, M. (2003). Authoring Interactive Software Simulations for e-Learning. In Unknown Host Publication IEEE Computer Society. http://csdl.computer.org/comp/proceedings/icalt/2003/1967/00/19670448abs.htm

Link to publication record in Ulster University Research Portal

\section{Published in:}

Unknown Host Publication

Publication Status:

Published (in print/issue): 01/07/2003

\section{Document Version}

Publisher's PDF, also known as Version of record

\section{General rights}

Copyright for the publications made accessible via Ulster University's Research Portal is retained by the author(s) and / or other copyright owners and it is a condition of accessing these publications that users recognise and abide by the legal requirements associated with these rights.

\section{Take down policy}

The Research Portal is Ulster University's institutional repository that provides access to Ulster's research outputs. Every effort has been made to ensure that content in the Research Portal does not infringe any person's rights, or applicable UK laws. If you discover content in the Research Portal that you believe breaches copyright or violates any law, please contact pure-support@ulster.ac.uk. 


\title{
Authoring Interactive Software Simulations for e-Learning
}

\author{
Maeve Paris \\ University of Ulster
}

\begin{abstract}
E-learning simulation authoring tools are the next generation of e-learning products: they enable tutors to create interactive multimedia course content. Users can walk through applications online and practise as they progress through course material. Much online course content is still based on paper models, but new media need new methods, and the growing availability of elearning simulation tools will enable both tutors and learners fully to exploit the multimedia possibilities that online learning offers. A case study illustrates the potential of simulations to enhance the delivery of instructional material in an academic context.
\end{abstract}

\section{Introduction}

Specialised tools which simulate the learning environment will be at the heart of the next generation of e-learning products [1]. This is a case study of the use of one such tool to author simulations to enhance courseware for an undergraduate computer science module in Natural Language Processing. Too much online course content is still paper-based: typically, tutors upload Microsoft Word or PowerPoint files to Virtual Learning Environments (VLEs) or websites [2].

\section{Software simulation authoring tools}

E-learning courseware design is still at an immature stage: browser-delivered e-learning tends to be served in the form of 'page-turning courseware' [1],[2]. Such an approach may not fit with student learning styles, especially in the area of IT or application training: it is difficult to create interactive content using conventional Web tools: HyperText Markup Language is best for static content, and providing dynamic content requires skills in programming languages like Visual Basic or Java. However, there has been a growth in the number of tools available which enable the development of simulation-based content.

\section{Case study using ViewletBuilder}

Viewlets are based on Projects, composed of screenshots. Fifty-four slides were created with a running time of approximately five minutes, viewable through any Internet browser. The Viewlet takes the viewer through the initial steps of writing a first Prolog program, loading it into the LPA WinProlog environment, querying the knowledge base, modifying and reloading the program, and making more complex queries. A sample screenshot is shown below

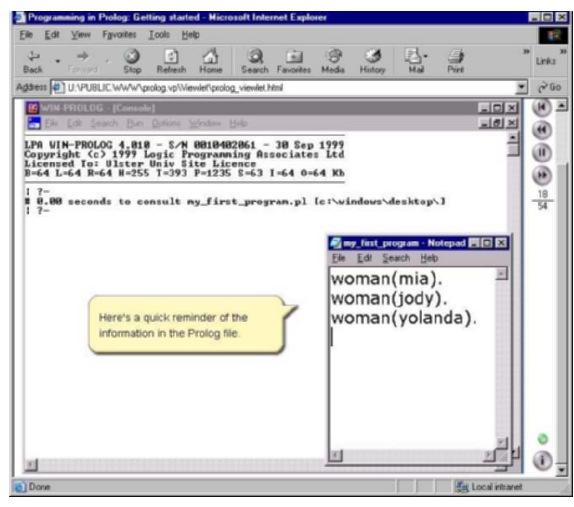

Figure 1. Screenshot from Viewlet

\section{Conclusions}

From the instructor's perspective, the ViewletBuilder environment is relatively easy to learn and small simulations can be created quickly. From the end user's perspective, the usability evaluation indicated a positive reaction to the application. The emergence of e-learning simulation tools may foster innovation in the provision of online course content: authors can use these tools as a new means of expression; users will benefit from the opportunity to interact with applications and practise at the same time: 'if e-learning is to engage the masses, it needs more interactive and accessible content. It's unlikely that webpage-turning will hold the students of the PlayStation era' [2].

\section{References}

[1] Brandon-Hall.com, E-Learning Simulations: Tools and Services for Creating Software, Business, and Technical Skills Simulations, Brandon-Hall, March 2002.

[2] E.Wilson, 'How to make e-learning interesting', The Sydney Morning Herald,

http://www.smh.com.au/articles/2002/09/21/103055002732.ht $\mathrm{m}, 2002$. 